ENTREPRENEURSHIP AND SUSTAINABILITY ISSUES

ISSN 2345-0282 (online) http://jssidoi.org/jesi/

2019 Volume 7 Number 2 (December)

http://doi.org/10.9770/jesi.2019.7.2(40)

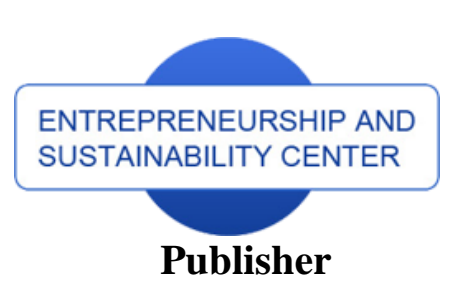

http://jssidoi.org/esc/home
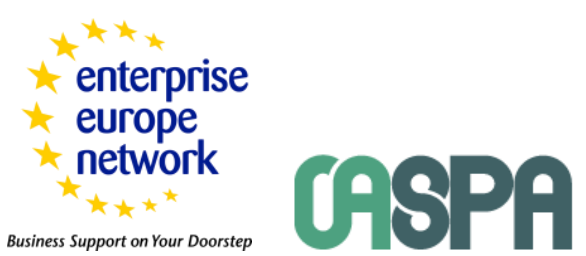

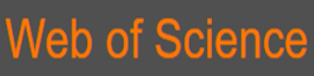

I. Clarivate

Analytics

\title{
MECHANISM TO ENSURE SUSTAINABLE DEVELOPMENT OF ENTERPRISES IN THE INFORMATION SPACE ${ }^{*}$
}

\author{
Akmal Durmanov', Viera Bartosova², Svetlana Drobyazko ${ }^{3}$, Oksana Melnyk ${ }^{4}$, Volodymyr Fillipov ${ }^{5}$ \\ ${ }^{1}$ Tashkent Institute of Irrigation and Agricultural Mechanization Engineers, 39 Kari Niyazov ko'chasi, Tashkent, Uzbekistan \\ ${ }^{2}$ University of Zilina, Univerzitna 1, 01026, Zilina, Slovak Republic \\ ${ }^{3 *}$ European academy of sciences, 111 New Union Street, Coventry, United Kingdom \\ ${ }^{4}$ Vadym Hetman Kyiv National Economic University, 54/1 Prospect Peremogy, 03680, Kyiv, Ukraine \\ ${ }^{5}$ Odessa national polytechnic university, Shevchenko Avenue, 1, 65044, Odesa, Ukraine \\ E-mail: ${ }^{3 *}$ drobyazko.s.i@gmail.com (corresponding author)
}

Received 15 August 2019; accepted 24 October 2019; published 15 December 2019

\begin{abstract}
There was developed the conceptual framework of information support of the management mechanism of sustainable development of enterprises, in order realize the continuous exchange of information between the controlling and controlled systems of the mechanism, provide the comparative analysis of variants of its improvement, as well as support the selection of effective management decision-making. The solution of the burning problem of ensuring sustainable development of enterprises, the scientific-theoretical justification and practical approaches to formation of the management mechanism of sustainable development, create the significant basis for keeping and expansion of the business activities of enterprises in terms of their transformational changes. Management of the sustainable development is reasonable to realize by the use of the appropriate mechanism as the bunch of successive and coordinated management methods and tools, applied by the management entities for the targeted development of enterprises. In accordance with the consistent characteristics of the object, criteria, principles in the work, the study estimated formation of the management mechanism of sustainable development of the enterprise. In contrast with the current mechanisms, the reporting one gives the enterprise the possibility of more content-related definition and justification of the directions of development; provides the high efficiency, flexibility and adaptability of the management system of the enterprise; guarantees the timeliness of identification of significant changes and development of the corresponding procedures; contributes to the continual improvement of the management processes of sustainable development of the enterprise, taking into account the variability of the market environment.
\end{abstract}

Key words: sustainable development; management mechanism; enterprise information system; information flows; information support

Reference to this paper should be made as follows: Durmanov, A., Bartosova, V., Drobyazko, S., Melnyk, O., Fillipov, V. 2019. Mechanism to ensure sustainable development of enterprises in the information space. Entrepreneurship and Sustainability Issues, 7(2), 1377-1386. http://doi.org/10.9770/jesi.2019.7.2(40)

JEL Classification: M21, O16

\footnotetext{
* This research was supported by the project, which has received funding from the Grant No. 1/0544/19 Formation of the methodological platform to measure and assess the effectiveness and financial status of non-profit organizations in the Slovak Republic.
} 


\section{Introduction}

The traditional methods of enterprise management are not effective enough in terms of the fast-paced competitive business environment. Sustainable development is one of the key factors ensuring the competitive ability for the enterprise, which operates in terms of the increasing uncertainty and dynamic-response of the environment. Therewith, management of sustainable development is the basic requirement for the efficiency of enterprises progress. Therefore, looking for ways to ensure the management process of sustainable development of enterprises, which should be adequate to the new economic conditions, is one of the burning issues of economic research.

It is the mechanism of management that is designed to influence the factors, which condition specify the performance results of the enterprise. Establishment of the perfect economic mechanism of regulation of business development of the enterprise is the objective condition for ensuring its effective functioning in terms of the contemporary transformations.

Functioning of the management mechanism of sustainable development of enterprises is contingent upon the appropriate information support, which, in our opinion, is a functional complex, covering the process of the continuous targeted selection of the corresponding information indicators, required for the analysis and preparation of the operating management decisions on all components of the enterprise management process. Therefore, the management of sustainable development of the enterprise comes down to the continuous process of information treatment, its analysis for the further development and managerial decision-making. As a result, on the one hand, information is the basis of sustainable development management, and on the other hand, it is the uncertainty factor.

In such case, solution of the issues of ensuring sustainable development of enterprises requires the periodic adjustment of the management methods as way to improve the management mechanism of sustainable development of the enterprise.

The purpose of the article is formation of the theoretical and application-oriented foundations of the management mechanism of sustainable development of enterprises to improve their performance efficiency.

\section{Literature Survey}

In present-day conditions, development of the economic entity is usually connected with the level of globalization and internationalization of the economic relations, intensification of the competitive activity both at the international and national levels, risks of the macroeconomic stability of the country, dynamics of parameters of the business environment, regional and industry characteristics of the economic functioning mechanism of enterprises.

The analysis of the listed versions of development allowed specifying the common features concerning the points of view on identification of the studied item, and uniting them into groups.

The first group of scientists related such development with the progress of the system and changes of the constructive character (Álvarez Jaramillo, J., Zartha Sossa, J. W., \& Orozco Mendoza, G. L. (2019), Liu, Z., Adams, M., Cote, R. P., Geng, Y., \& Li, Y. (2018)). It should be noted that development does not always contribute to the progress and structural changes (Voegtlin, C., \& Scherer, A. G. (2017)). Also, the reverse 


\section{ENTREPRENEURSHIP AND SUSTAINABILITY ISSUES}

ISSN 2345-0282 (online) http://jssidoi.org/jesi/

2019 Volume 7 Number 2 (December)

http://doi.org/10.9770/jesi.2019.7.2(40)

processes can become the results of development - regression, in other words such development that has destructive nature (Drobyazko, S., et al. (2019)).

At the same time, in our opinion, highlighting of the neutral course of development comes in conflict with definition of the development process. Movement is the integral part of development, which means the constant change of the status, and the concept of "development" is considered as the result of a range of transformations, which recently happened (Bombiak, E., \& Marciniuk-Kluska, A. (2018)). Therefore, the selection of the neutral course of development is possible in theory only (Kolk, A., Kourula, A., \& Pisani, N. (2017), Baltgailis, J. (2019)).

The second group of scientists characterized the development process as quantitative and qualitative character changes in the system structure (Garbowski, M., et al. (2019), Liao, S. H., et al. (2017)). However, in addition to changes, there is the concept of the system performance (Van Zanten, J. A., \& Van Tulder, R. (2018)).

On the one hand, functioning is driven by the support of the common vital functions (Jansson, J., Nilsson, J., Modig, F., \& Hed Vall, G. (2017)), and on the other hand, it is the basis for new transformations, which will definitely determine the nature and direction of development (Johnson, M. P. (2017), Wu, G. C. (2017)).

The third group of researchers believed that development is the process of adaptation to changes of the external environment Vázquez Maguirre, M., Portales, L., \& Velásquez Bellido, I. (2018)). Such adaptability of the system is required for its functioning and development, but it is not good enough (Hilorme, T., et al. (2019a), Hilorme, T., et al. (2019b)).

In order to ensure sustainable development, the enterprises need to form the more improved management system, which would better register the uncertainty of the external environment (Zhang, Y., et al. (2017)).

The issues related to formation of the management mechanism of sustainable development of enterprises still remained unattended by scientists. At the same time, it is important to look for more effective methods of organization and management in terms of the constantly changing macroeconomic factors. It will ensure achievement of the certain strategic goal of enterprises development in terms of the innovation-driven development.

\section{Methods}

The clauses of the classical and present-day theories of management and development of enterprises, as well as scientific works of scientists on sustainable development, form the methodological basis of the study.

In terms of the study realization we used the following methods: critical analysis and generalization of the theoretical studies (for determination of the trends in sustainable development of the enterprise); economic and statistical (analysis the enterprises performance and formation of the valuation methods of sustainable development of enterprises); factor analysis (identification of the most effective impact factors on sustainable development); mathematical modeling; graphic approach (for visualization of the study findings).

\section{Results}

The concept of the management mechanism of sustainable development of enterprises and the critical estimation of the management mechanism of sustainable development require some focusing on working out of the specific action-oriented recommendations for its improvement. We believe that the management methods of sustainable development of enterprises are the basis of action-oriented recommendations. 


\section{ENTREPRENEURSHIP AND SUSTAINABILITY ISSUES}

ISSN 2345-0282 (online) http://jssidoi.org/jesi/ 2019 Volume 7 Number 2 (December) http://doi.org/10.9770/jesi.2019.7.2(40)

On the basis of the exceptional importance of information as the interconnection foundation between the constituent elements of the management mechanism, we propose to consider the management of information flows in terms of the management mechanism of sustainable development of enterprises.

In addition, it is quite necessary to have the required information on the methods of effective combination of the physical and intangible resources, which contributes to formation of the sustainable competitive advantages. However, the issue of information support of the management mechanism of sustainable development of the enterprise received little attention. The functions of information provision formed into the independent industry, but quite insufficiently structured and integrated into the management system.

Table 1. Classification of the information flows, circulating in the management mechanism of sustainable development of the enterprise (original development)

\begin{tabular}{|c|c|c|}
\hline Classification features & Types of flows & Characteristics of information flows \\
\hline \multirow[t]{2}{*}{ By the enterprise } & Input flows & $\begin{array}{l}\text { Market information (prices, product range, number of competitors) } \\
\text { Information from suppliers, counterparties (contracts) } \\
\text { Customer-related information (demographic, social information, customer } \\
\text { satisfaction level) } \\
\text { Information from the authorities (civil, labour, tax legislation, tenders for } \\
\text { participation in the government programs) } \\
\text { Information from the superior management entities (owners of the management } \\
\text { company) }\end{array}$ \\
\hline & Output flows & $\begin{array}{l}\text { Information for suppliers, counterparties (commercial offers, contracts) } \\
\text { Customer information (advertising, technical support) } \\
\text { Information for the authorities (tax, statistical reporting) } \\
\text { Information for the superior management entities }\end{array}$ \\
\hline $\begin{array}{l}\text { By the management system } \\
\text { levels }\end{array}$ & $\begin{array}{l}\text { Horizontal } \\
\text { Vertical }\end{array}$ & $\begin{array}{l}\text { Have the coordination nature } \\
\text { Depend on the management hierarchy levels }\end{array}$ \\
\hline $\begin{array}{c}\text { By the management process } \\
\text { organization }\end{array}$ & $\begin{array}{l}\text { Motivating } \\
\text { Explanatory }\end{array}$ & $\begin{array}{l}\text { Determine the choice of the targeted impact } \\
\text { Contain information about the presence, condition and functioning of the system } \\
\text { Provide the targeted impact on the controlled object }\end{array}$ \\
\hline By the formality level & $\begin{array}{l}\text { Formal } \\
\text { Informal }\end{array}$ & $\begin{array}{l}\text { Official } \\
\text { Informal }\end{array}$ \\
\hline By the flow carriers & $\begin{array}{l}\text { Verbal } \\
\text { Documentary } \\
\text { Electronic }\end{array}$ & $\begin{array}{l}\text { Oral } \\
\text { In the view of paper documents } \\
\text { In the view of electronic documents, messages, transactions }\end{array}$ \\
\hline
\end{tabular}

There are many software products on the market of information services, which mainly contribute in closing the gaps in the information technologies of enterprises. At the same time, establishment of software support does not provide any long-running results without the preliminary preparations and adjustment of the organizational system of information support, its coordination with the configuration of the operating and business performance and structure of the enterprise.

Taking into account the urgent need for special technologies of accounting, registration, storage and mobilization of information resources, we propose to highlight the following elements, which form "the structure" of information support for the management mechanism of sustainable development of enterprises. 


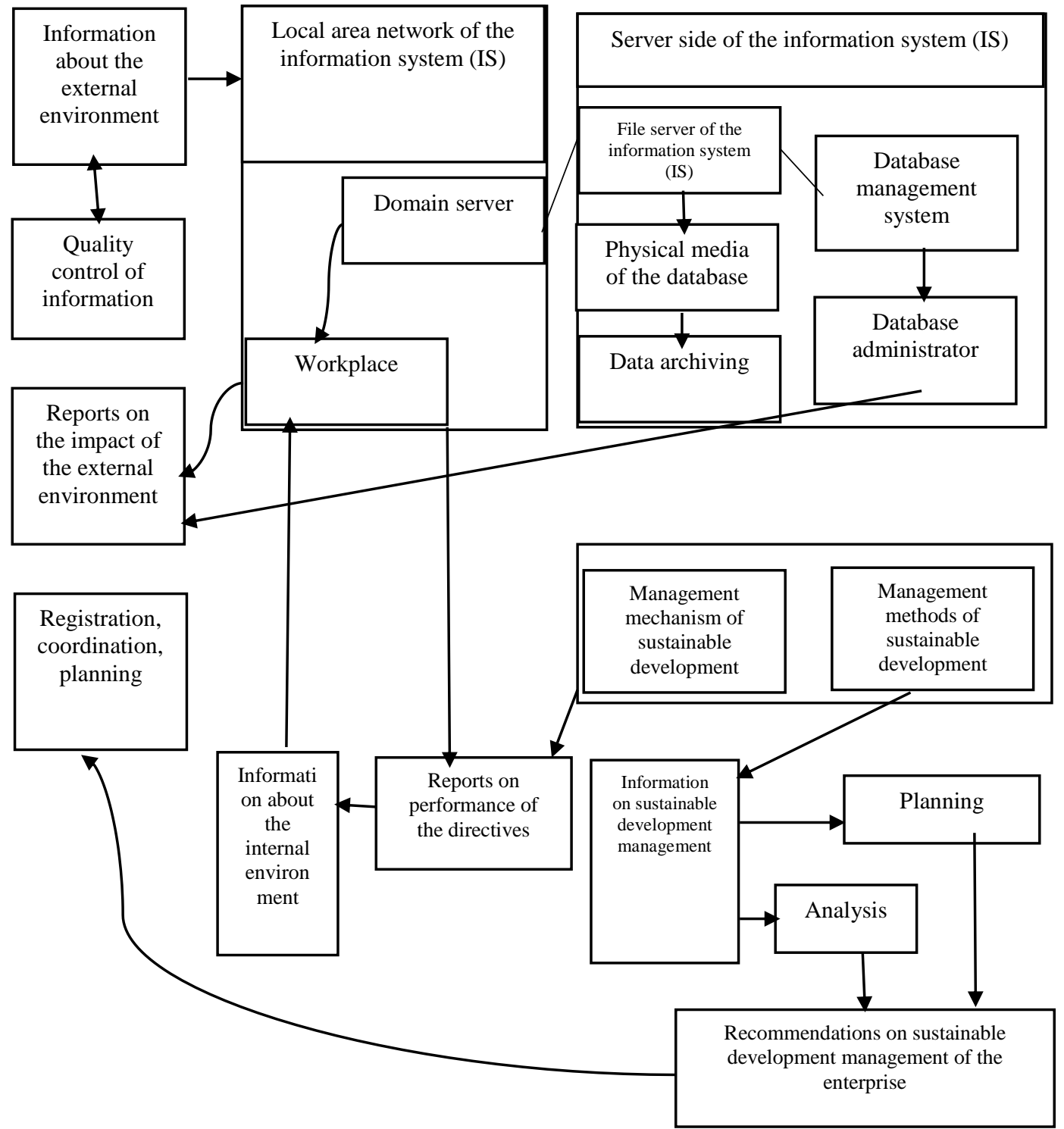

Figure 1. Information system for ensuring the management mechanism of sustainable development of the enterprise (original development) 


\section{ENTREPRENEURSHIP AND SUSTAINABILITY ISSUES}

ISSN 2345-0282 (online) http://jssidoi.org/jesi/ 2019 Volume 7 Number 2 (December) http://doi.org/10.9770/jesi.2019.7.2(40)

In the reporting terms, the information support is designed to synchronize the business objectives and the growing information needs of the enterprise to optimize the IT infrastructure parameters, in order to prevent the structural and managerial crises.

Information assessment is the mechanism that keeps the information support in the updated form. Among the general bunch of information flows in the management mechanism of sustainable development of enterprises, we should highlight two main types (two parameters of the system, which provides management functions), namely: information received from the internal environment of the enterprise, and information received from the external environment of the enterprise.

Therefore, the information flows of the enterprise have both quantitative and qualitative characteristics, which we used for making the classification for improvement of the management mechanism of sustainable development of enterprises (Table 1).

The diagram of the information system for ensuring sustainable development of the management mechanism of the enterprise is illustrated in the Figure 1.

The hardware and software of the enterprise information system is proposed as the basis of the reporting system, which combines into the local area network of the information system. The network consists of the server and front-end sides. The capabilities of the server side of the information system support the functions of the database management system, work with files of the information system, service functions that are associated with data backup, recovery, and archiving.

The front-end capabilities support the operation of application-oriented software, which covers the functions of the enterprise management automation.

The front-end side of the information system consists of workplaces - computers, which have the installed frontend side of the application-oriented software of the information system. There is given a communication between the reporting workplaces (workstations) and the server side of the information system, on the basis of the "clientserver" technology.

Also, the information system software installed in the workplaces supports the functions related to sustainable development of the management mechanism. Actually, it is the calculation of all indicators required for the analysis and management of sustainable development, preparation of information and making recommendations in accordance with the methods of sustainable development management.

Workstations software is directly linked to the management mechanism of sustainable development. The reporting connection resides in the fact that the information flow about the condition of environment passes through the application-oriented software of the management automation. The capabilities of such ensuring are usually used for the quality control of information on the external environment, and forming of the reports about influence of the external environment on the enterprise.

\section{Discussion}

Recognition of the internal actions on sustainable development of the enterprise is usually associated with data that are formed on the basis of the use of the management methods of sustainable development that are applied to real reporting information on the business activities of the enterprise for many previous periods, as well as realization of the directives. 


\section{ENTREPRENEURSHIP AND SUSTAINABILITY ISSUES}

ISSN 2345-0282 (online) http://jssidoi.org/jesi/ 2019 Volume 7 Number 2 (December) http://doi.org/10.9770/jesi.2019.7.2(40)

On the other hand, information on the management results of sustainable development is subject to economic analysis. All further work of the enterprise is planned on its basis. The results of the analysis and planning became the basis for development of recommendations for the management of sustainable development of the enterprise. The developed recommendations for the management of sustainable development of the enterprise are subject to registration, they should be taken into account in terms of the coordination and planning of the enterprise for a period ahead. In such case, there is developed the cycle (recursive) closure of the enterprise work: the input information about the past activities of the enterprise and past external influences through its processing in the information system of ensuring the management mechanism of sustainable development, contributes to development of the further recommendations on the business activities of the enterprise. In such recursive closure, working out of the sustainable development management, its realization, monitoring of compliance, analysis of results, and again development of the management recommendations, are actively rotated.

Finally, information about the internal environment, received from the reporting data and through the analysis and planning, enters the information system through the appropriate application-oriented software. In addition, it is subject to registration and coordination with the relevant information regarding the external environment. Thereupon, they produce the revised plans that take into account the external and internal influence on sustainable development of the enterprise.

Thus, ensuring the information support of sustainable development is the functional add-in over the information system of the enterprise. The information support performs the functions of accumulation, analysis, coordination of received data for the automated drawing up of recommendations for the management of sustainable development of the enterprise.

\section{Conclusions}

Information receiving and transferring provides the enterprise with the opportunity to obtain the additional value from the internal dissemination of information, the faster access to information and common standards of information exchange. The information infrastructure synchronizes the business objectives and the growing information needs of the enterprise to optimize the IT infrastructure parameters, in order to prevent the structural and managerial crises. Information assessment is the mechanism, which keeps the information support in the updated form.

The study covers the information flows, representing the preparation, realization and control of sustainable development management, and specifies the structure of the system of its information support. As a result, it provided the basis for development of action-oriented recommendations for establishment of the worked out management mechanism of sustainable development in the enterprise information systems.

There was developed the conceptual framework of information support of the management mechanism of sustainable development of enterprises, which allowed ensuring the well-coordinated work of all levers of the structural configuration of the mechanism, as well as understand who manages the mechanism, when they make control, and what levers are used to manage.

On the basis of the complex management methods of sustainable development, modeling of sustainable development, information support of sustainable development, there was improved the management mechanism of sustainable development of the enterprises. The defined management mechanism was proposed to construct as the open management system, which is able to expand and supplement, as well as integrate into the existing information systems. 


\section{ENTREPRENEURSHIP AND SUSTAINABILITY ISSUES}

ISSN 2345-0282 (online) http://jssidoi.org/jesi/ 2019 Volume 7 Number 2 (December) http://doi.org/10.9770/jesi.2019.7.2(40)

The information support of sustainable development of the enterprises is the key element of improving the management mechanism of sustainable development of the enterprises. Because without the support, there will be the complete deficit of well-coordinated work of all levers of the structural configuration of the mechanism, or it will not be obvious who manages the mechanism, as well as when and what levers are used to manage.

\section{References}

Álvarez Jaramillo, J., Zartha Sossa, J. W., \& Orozco Mendoza, G. L. (2019). Barriers to sustainability for small and medium enterprises in the framework of sustainable development - Literature review. Business Strategy and the Environment, 28(4), 512-524. URL: https://onlinelibrary.wiley.com/doi/abs/10.1002/bse.2261

Baltgailis, J. 2019. The issues of increasing the effectiveness of teaching comparative economics. Insights into Regional Development, 1(3), 190-199. https://doi.org/10.9770/ird.2019.1.3(1)

Bombiak, E., \& Marciniuk-Kluska, A. (2018). Green human resource management as a tool for the sustainable development of enterprises: Polish young company experience. Sustainability, 10(6), 1739. URL: https://www.mdpi.com/2071-1050/10/6/1739

Garbowski, M., Drobyazko, S., Matveeva, V., Kyiashko, O., \& Dmytrovska, V. (2019). Financial accounting of E-business enterprises. Academy of Accounting and Financial Studies Journal, 23(2).

Drobyazko, S., Potyshniak, O., Radionova, N., Paranytsia, S., Nehoda, Y. (2019). Security of organizational changes via operational integration: ensuring methodology. Journal of Security and Sustainability Issues, 9(1), 1595-1612. http://doi.org/10.9770/jssi.2019.9.1(8)

Hilorme T., R. Shurpenkova, O.Kundrya-Vysotska, O. Sarakhman, O. Lyzunova (2019). Model of energy saving forecasting in entrepreneurship. Journal of Entrepreneurship Education, 22, Special Issue: 1S. URL: https://www.abacademies.org/articles/model-ofenergy-saving-forecasting-in-entrepreneurship-7994.html

Hilorme, T., Perevozova, I., Shpak, L., Mokhnenko, A. \& Korovchuk, Yu. (2019). Human Capital Cost Accounting in the Company Management System. Academy of Accounting and Financial Studies Journal, 23, Special Issue $2 . \quad$ URL: https://www.abacademies.org/articles/human-capital-cost-accounting-in-the-company-management-system-8412.html

Jansson, J., Nilsson, J., Modig, F., \& Hed Vall, G. (2017). Commitment to sustainability in small and medium-sized enterprises: The influence of strategic orientations and management values. Business Strategy and the Environment, 26(1), 69-83. URL: https://onlinelibrary.wiley.com/doi/full/10.1002/bse.1901

Johnson, M. P. (2017). Knowledge acquisition and development in sustainability-oriented small and medium-sized enterprises: Exploring the practices, capabilities and cooperation. Journal of cleaner production, 142, 3769-3781. URL: https://www.sciencedirect.com/science/article/pii/S0959652616316985

Kolk, A., Kourula, A., \& Pisani, N. (2017). Multinational enterprises and the Sustainable Development Goals: What do we know and how to proceed? Transnational Corporations, 24(3), 9-32. URL: https://papers.ssrn.com/sol3/papers.cfm?abstract_id=2988607

Liao, S. H., Chen, C. C., Hu, D. C., Chung, Y. C., \& Yang, M. J. (2017). Developing a sustainable competitive advantage: absorptive capacity, knowledge transfer and organizational learning. The Journal of Technology Transfer, 42(6), 1431-1450. URL: https://link.springer.com/article/10.1007/s10961-016-9532-1

Liu, Z., Adams, M., Cote, R. P., Geng, Y., \& Li, Y. (2018). Comparative study on the pathways of industrial parks towards sustainable development between China and Canada. Resources, conservation and recycling, 128, 417-425. URL: https://www.sciencedirect.com/science/article/pii/S0921344916301495

Van Zanten, J. A., \& Van Tulder, R. (2018). Multinational enterprises and the Sustainable Development Goals: An institutional approach to corporate engagement. Journal of International Business Policy, 1(3-4), 208-233. URL: https://link.springer.com/article/10.1057/s42214$\underline{018-0008-\mathrm{x}}$

Vázquez Maguirre, M., Portales, L., \& Velásquez Bellido, I. (2018). Indigenous social enterprises as drivers of sustainable development: Insights from Mexico and Peru. Critical Sociology, 44(2), 323-340. https://journals.sagepub.com/doi/abs/10.1177/0896920516688757 


\section{ENTREPRENEURSHIP AND SUSTAINABILITY ISSUES}

ISSN 2345-0282 (online) http://jssidoi.org/jesi/

2019 Volume 7 Number 2 (December)

http://doi.org/10.9770/jesi.2019.7.2(40)

Voegtlin, C., \& Scherer, A. G. (2017). Responsible innovation and the innovation of responsibility: Governing sustainable development in a globalized world. Journal of Business Ethics, 143(2), 227-243. URL: https://link.springer.com/article/10.1007/s10551-015-2769-Z

Wu, G. C. (2017). Effects of socially responsible supplier development and sustainability-oriented innovation on sustainable development: Empirical evidence from SMEs. Corporate Social Responsibility and Environmental Management, 24(6), 661-675. URL: https://onlinelibrary.wiley.com/doi/abs/10.1002/csr.1435

Zhang, Y., Zhao, T., Zhang, Z., Wan, J., Feng, X., Liang, X., \& Zhou, A. (2017). Modeling and dynamic assessment on sustainable development of drainage enterprise: Application of a coupled system dynamics-comprehensive assessment model. Journal of cleaner production, 141, 157-167. URL: https://www.sciencedirect.com/science/article/pii/S0959652616313968

\section{Aknowledgements}

This research was supported by the project, which has received funding from the Grant No. 1/0544/19 Formation of the methodological platform to measure and assess the effectiveness and financial status of non-profit organizations in the Slovak Republic. 
Akmal DURMANOV, Senior Lecturer, Department of Management, Tashkent Institute of Irrigation and Agricultural Mechanization Engineers. Tashkent, Uzbekistan

ORCID ID: orcid.org/0000-0003-4509-3915

Viera BARTOSOVA, Ph.D in Economics, Associate Professor, University of Zilina, Zilina, Slovak Republic ORCID ID: orcid.org/0000-0001-7960-4429

Svetlana DROBYAZKO, Ph.D in Economics, Professor, European academy of sciences, Coventry, United Kingdom ORCID ID: orcid.org/0000-0003-2022-0126

Oksana MELNYK, Associate Professor, Kyiv National Economic University named after Vadym Hetman, Kyiv, Ukraine ORCID ID: orcid.org/0000-0003-4429-7582

Volodymyr FILIPPOV, PhD, Associate Professor of the Management Chair, Odessa national polytechnic university ORCID ID: orcid.org/0000-0003-4429-7582

Copyright (C) 2019 by author(s) and VsI Entrepreneurship and Sustainability Center

This work is licensed under the Creative Commons Attribution International License (CC BY).

http://creativecommons.org/licenses/by/4.0/

C) (i) Open Access 